(C) 2019 by the Arizona Board of Regents on behalf of the University of Arizona. This is an Open Access article, distributed under the terms of the CreativeCommons Attribution-NonCommercial-ShareAlike licence (http://creativecommons.org/licenses/by-nc-sa/4.0/), which permits non-commercial re-use, distribution, and reproduction in any medium, provided the same Creative Commons licence is included and the original work is properly cited. The written permission of Cambridge University Press must be obtained for commercial re-use.

\title{
RADIOCARBON AMS DATING OF MESOLITHIC HUMAN REMAINS FROM POLAND
}

\author{
Natalia Piotrowska ${ }^{1 *} \cdot$ Jacek Tomczyk $^{2} \cdot$ Sławomira Pawełczyk $^{1} \cdot$ Lukasz M Stanaszek $^{3}$ \\ ${ }^{1}$ Silesian University of Technology, Institute of Physics - CSE, Division of Radioisotopes, Gliwice, Poland \\ ${ }^{2}$ Cardinal Wyszynski University, Faculty of Christian Philosophy, Institute of Ecology and Bioethics, Warsaw, Poland \\ ${ }^{3}$ State Archaeological Museum Warsaw, Anthropological Laboratory, Warsaw, Poland
}

\begin{abstract}
Biological studies on Mesolithic human remains from the Polish region are a rare subject of scientific research due to the limited number of these relics and their poor state of preservation. From the project titled "Old material with new methods: Using the latest bio-chemical analysis in studies of Mesolithic human remains from the Polish areas," the radiocarbon $\left({ }^{14} \mathrm{C}\right)$ dating of bones using accelerator mass spectrometry (AMS) has been performed. For these experiments, the gelatin was extracted from bones, and its quality evaluated by the $\mathrm{C} / \mathrm{N}_{\mathrm{at}}$ ratio and the stable isotope composition of both carbon and nitrogen. The ${ }^{14} \mathrm{C}$ results have been obtained for 11 bone samples from 5 sites, and throughout this work the results of two preparation methods are compared. The simple gelatin extraction provided material with unsatisfactory collagen quality indicators, while additional alkali treatment allowed us to obtain much more reliable, and generally older, results. Additionally, analysis on VIRI/SIRI samples were conducted to test the developed method. Only seven of the investigated bone samples yielded ages within Mesolithic period, and the most reliable dates range from 5800 to $6800 \mathrm{cal} \mathrm{BC}$. One sample was not datable, and two were shown to be much younger than expected.
\end{abstract}

KEYWORDS: $\mathrm{C} / \mathrm{N}_{\mathrm{at}}$, human bones, Mesolithic, radiocarbon AMS dating, stable isotopes.

\section{INTRODUCTION}

Human remains, dating back to the Mesolithic period in Poland (8000-4500 BC), are a unique and important knowledge source of the many issues related to biology and social life in the oldest human populations (e.g. Gumiński 1995; Lillie and Richards 2000; Schulting and Richards 2001; Sulgostowska 2006). This results mainly from the limited number of wellpreserved human bones, both in the whole Europe and in particular in Poland (e.g. Kozłowski 1998). Mesolithic human remains are precious and rare findings, thus their analysis was usually restricted to descriptive macroscopic research (e.g. Stęślicka-Mydlarska 1954; Szlachetko et al. 1964; Gładykowska-Rzeczycka 1973; Wiercińska and Szlachetko 1977). However, nondestructive research methods, which today are used in bioarchaeological research allow for a return to the old material (e.g. Tomczyk et al. 2014) and validation of the previously studied materials and sites, as well as reassessment of conclusions drawn dozens of years ago. At present in Europe and in the world, Mesolithic remains are a subject to detailed, multidisciplinary analyses, performed according to the latest methodological approach (e.g. Pazdur et al. 2004; Szostek et al. 2005; Meiklejohn et al. 2010). These novel technological analyses provide negligible invasion to the investigated material and does not deprive the specimens of their museum and exhibition value.

The scientific aim of the present project is to apply accelerator mass spectrometry radiocarbon (AMS ${ }^{14} \mathrm{C}$ ) dating to Mesolithic human remains (bone and sometimes tooth material) from five archaeological sites in Poland: Janisławice, Giżycko-Perkunowo, Warsaw-Grochów, Wieliszew, and Woźna Wieś. Although the discovery of Mesolithic material took place over 40 years ago, archaeological analyses only included information about the context of discovery

*Corresponding author. Email: natalia.piotrowska@polsl.pl. 
of the remains, the type of burial, and artifacts associated with the graves. Similarly, anthropological research only had a macroscopic character, when the material was measured and its anatomy described (Stęślicka-Mydlarska 1954; Wiercińska and Szlachetko 1977). Recent biological studies, including anthropology and genetics, were performed only for the remains of the Janisławice hunter (Stanaszek and Mańkowska-Pliszka 2013; Witas et al. 2013).

The scarcity of the analytical results for such an important archaeological material triggered this project, which is aimed at using the latest bio-chemical analysis to investigate the Mesolithic human remains from Polish regions. The project is completed collaboratively by a team of anthropologists, geneticists, physicists, and specialists in history and archaeology. The research material was transported to the Department of Biological Anthropology Cardinal Stefan Wyszynski University (Warsaw). The osteological material was described using a standard procedure as given in the Standards for Data Collection from Human Skeletal Remains (Buikstra and Ubelaker 1994). The protocol contains the following observations: (1) sex and age-at-death assessment, (2) metric skull measurements, (3) metric measurements of the postcranial skeleton, and (4) observation of non-metric skeletal traits. During this phase of research, the bone material was subsampled and transported to other specialist laboratories for genetic testing, isotopic determination, and ${ }^{14} \mathrm{C}$ dating.

The results presented hereafter will focus on the ${ }^{14} \mathrm{C}$ analysis of the remains by AMS, stable carbon $\left(\delta^{13} \mathrm{C}\right)$ and nitrogen $\left(\delta^{15} \mathrm{~N}\right)$ isotope determination, as well as the $\mathrm{C} / \mathrm{N}$ ratio; which will be mainly used as sample (in fact, the "collagen" sensu van Klinken 1999) quality indicators. The oxygen isotope composition, sequencing of genetic material, and the analysis of changes in the tooth enamel using SEM and x-ray techniques is being conducted simultaneously by collaborative research teams. Moreover, the extensive isotopic studies on the diet reconstruction, including measurement of the components in the food chain is an ongoing study.

The diagnostics of collagen extracted from bones for the purpose of ${ }^{14} \mathrm{C}$ dating and isotope studies can be provided by several measurable parameters (DeNiro 1985; Ambrose 1990; van Klinken 1999). The collagen yield should exceed $1 \%$, and the percentage of elements should be $15.3-47 \%$ for carbon and $5.5-17.3 \%$ nitrogen, by mass. Atomic $C / \mathrm{N}_{a t}$ ratios, indicating good preservation, should ideally fall within the range equal to the values obtained for modern animals and humans $\left(\mathrm{C} / \mathrm{N}_{\mathrm{at}}=2.9-3.6\right.$; Ambrose 1990). Following the work of Brock et al. (2010) and Tisnerat-Laborde et al. (2003), a C/N $\mathrm{N}_{\mathrm{at}}$ higher than recommended values indicates on a strong diagenesis or/and the presence of considerable amount of humic substances.

The carbon and nitrogen stable isotopic ratios of collagen depend on the diet of an individual. In a typical European inland case, exclusive of $\mathrm{C}_{4}$ plants and marine food resources, the $\delta^{13} \mathrm{C}$ value for adult bone collagen falls within a range of $-19 \%$ to $-22 \%$, while $\delta^{15} \mathrm{~N}$ may cover a much wider range, e.g. from $2 \%$ to $12 \%$ (van Klinken 1999). For the Eastern Baltic area (inland areas in Lithuania), the values for the Late Mesolithic and Subneolithic bones range from $-21 \%$ o to $-23.5 \%$ for $\delta^{13} \mathrm{C}$ and $10.5 \%$ o to $13 \%$ or $\delta^{15} \mathrm{~N}$ (Piličiauskas et al. 2018).

Elevated $\delta^{15} \mathrm{~N}$ values could indicate a considerable proportion of marine or freshwater component in the diet, which should imply the application of a relevant reservoir correction to the ${ }^{14} \mathrm{C}$ dates (e.g. Schulting and Richards 2001; Cook et al. 2001; Olsen et al. 2010; Svyatko et al. 2015; Marchenko et al. 2015). However, for the SE Baltic region the freshwater reservoir effect (FRE) reported by Piličiauskas and Heron (2015) is highly variable and site dependent, extending from non-present to a few centuries. 
In case of children, breast-feeding alters the stable isotope composition. In particular, the $\delta^{15} \mathrm{~N}$ increases by ca. $+3 \%$ o during breast-feeding, and after weaning the $\delta^{15} \mathrm{~N}$ value approaches that of adults with a similar diet (e.g. Fuller et al. 2006). Also, collagen $\delta^{13} \mathrm{C}$ values in young children's bones are enriched, due to the so-called "carnivore" effect, which may reach ca. 1\%o (e.g. Richards et al. 2002; Fuller et al. 2006).

In any case, a combination of all $\mathrm{C} / \mathrm{N}_{\mathrm{at}}$ and stable isotope data measured on exactly the same material, which was subjected to ${ }^{14} \mathrm{C}$ dating, provides a valuable tool for either pre-screening the material before dating or critical evaluation of previously obtained ${ }^{14} \mathrm{C}$ dates, as shown by e.g. van Klinken (1999), Svyatko et al. (2015), and Marchenko et al. (2015). Scirè Clabrisotto et al. (2013) reported that reasonable agreement with expected age may be obtained when $\mathrm{C} / \mathrm{N}_{\mathrm{at}}$ is slightly above the upper limit of the recommended range.

\section{MATERIAL}

This manuscript reviews the osteological material from five Mesolithic sites in Poland. In addition, three bone samples from international ${ }^{14} \mathrm{C}$ intercomparison programmes VIRI and SIRI (Scott et al. 2010, 2017) were subjected to the same ${ }^{14} \mathrm{C}$ dating procedures as archaeological samples.

The sites are located in two regions in Poland: Mazovia (Janisławice, Warsaw-Grochów, Wieliszew XI) and northeastern Poland (Giżycko-Pierkunowo, Woźna Wieś). The location of the sites is presented in Figure 1. The material was deposited at the State Archaeological Museum in Warsaw and the Institute of Archaeology and Ethnology of the Polish Academy of Sciences in Warsaw.

\section{Janisławice}

The most famous Mesolithic skeleton from Poland comes from Janisławice (51 $50^{\prime} 44^{\prime \prime} \mathrm{N} 20^{\circ}$ $03^{\prime} 18^{\prime \prime}$ E; Chmielewska 1954; Figure 1). These are the human bone remains of a 30 to 40 -yearold male and were discovered in a sitting position, the find was excavated in 1936-1937. The remains were accompanied by numerous artifacts identified as the hunter's accessories. The remains were initially investigated and described in detail by Stęślicka-Mydlarska (1954) and these observations were revised a couple of times later (Cyrek 1978; Sulgostowska 1990a; Stanaszek and Mańkowska-Pliszka 2013). The first ${ }^{14} \mathrm{C}$ analysis of the red deer antler was conducted in 1975 but was unsuccessful due to an insufficient collagen amount (Sulgustowska 1990a). The ${ }^{14} \mathrm{C}$ dating of collagen from the femur bone was performed in the Gliwice Radiocarbon Laboratory in 1985 with use of the radiometric technique (gas proportional counting) and provided an age of $6580 \pm 80{ }^{14} \mathrm{C}$ BP (Gd-2432), as reported by Sulgustowska (1990a) and Pazdur et al. (1994). The anthropological studies were carried out in 2015, but they did not contain any chronological analysis (Stanaszek and Mańkowska-Pliszka 2015). From this skeleton, two fragments were subjected to this present study: one from femur (named Janisławice Femur) and the second from tibia bone (Janisławice Tibia). The bones have not been subjected to any conservatives.

Additional bone fragments from the Janisławice hunter were discovered in a museum collection archive. A sample of cortical bone fragment was acquired for ${ }^{14} \mathrm{C}$ AMS dating (named Janisławice 2), however, the placement and description of this finding was unsatisfactory, thus the association of this material with the previously escribed hunter bones is uncertain. 


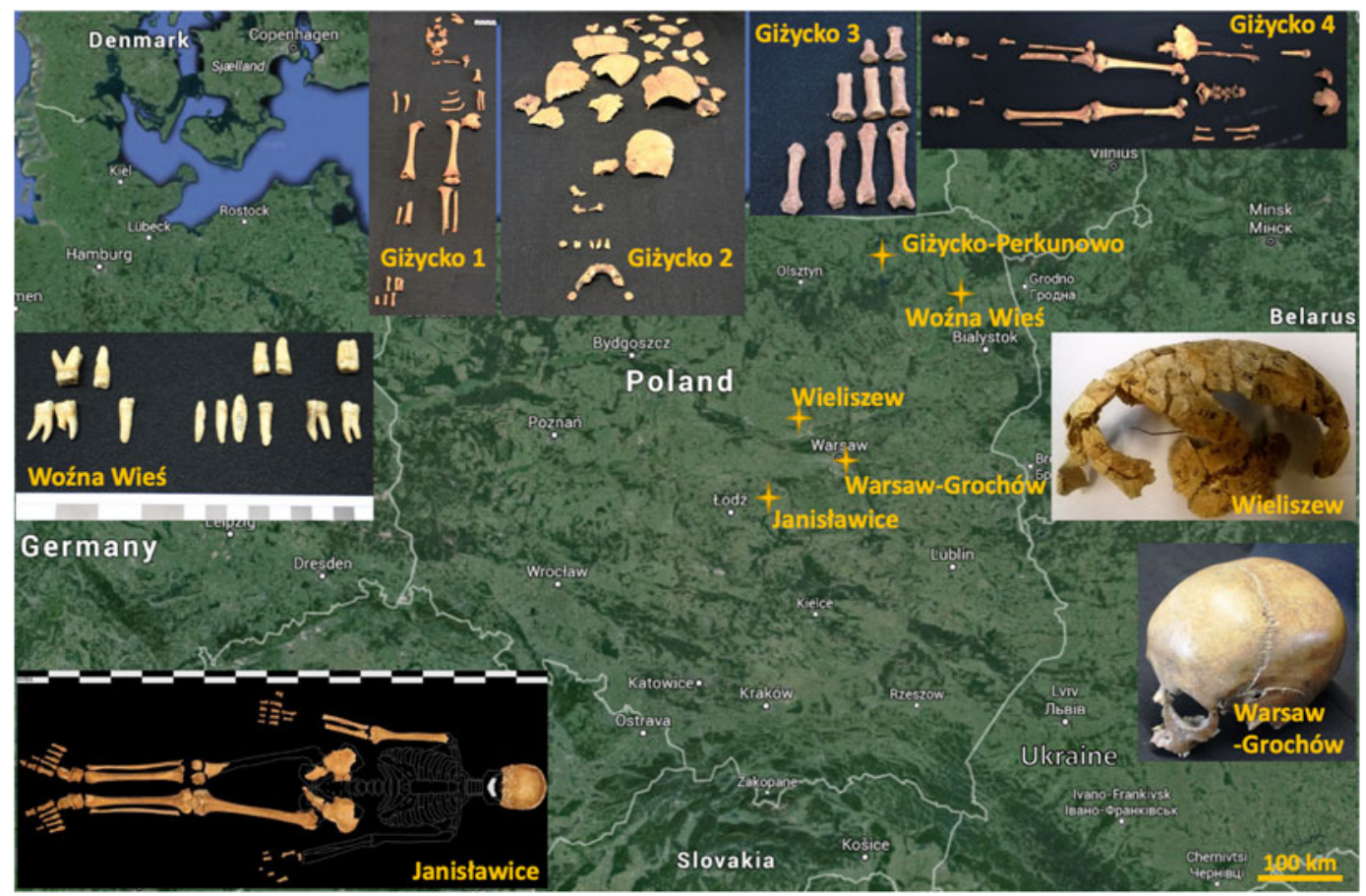

Figure 1 Location of the five Mesolithic sites from the two regions: northeastern Poland (Giżycko-Pierkunowo, Woźna Wieś) and the Mazovia region (Wieliszew, Warsaw-Grochów, Janisławice). The insets present the osteological material collected at each site. Background map from www.google.com/maps.

\section{Giżycko-Pierkunowo}

In July 1965, two graves with skeletons were explored in the Pierkunowo village, near Giżycko in the Mazurian Lakeland $\left(54^{\circ} 04^{\prime} 20^{\prime \prime} \mathrm{N} 21^{\circ} 43^{\prime} 50^{\prime \prime} \mathrm{E}\right.$; Figure 1) by the State Archaeological Museum in Warsaw. The graves were situated about $35 \mathrm{~m}$ from the south-eastern shore of Lake Kisajno. The graves were flat pit-graves without any stone setting. The skeletons, found in lying position, were dyed with ochre (Głosik 1969a).

Four skeletons from three separate graves were sampled for this study. Samples Giżycko 1 (rib fragment from ca. 3-yr-old child skeleton) and Giżycko 4 (phalanx of female adult, 35-39 yr old), both come from the first grave. From the second grave, phalanx bones of a child, ca. 18 months old, were collected (sample named Giżycko 2), and rib bones of and adult (sex and age undetermined) came from the third grave and termed Giżycko 3. The material was not conserved.

Prior to the ${ }^{14} \mathrm{C}$ dating, a chemical method based on fluorine and chlorine content in bone mineral fraction (Wysoczański-Minkowicz 1979) was applied to the female adult bone from this site. The obtained age was $3750 \pm 150$ BC (Głosik 1969b), which is inconsistent with the archaeological evidence.

\section{Warsaw-Grochów}

The human remains (only the cranium, see Figure 1) of so-called "little girl from Grochów" (8-9 yr old) were accidentally discovered in 1961 and they are considered to be the oldest 
excavated human bones in the Warsaw area. The discovery took place during trench digging on the Nowokinowa street in Grochów (eastern part of Warsaw; $52^{\circ} 14^{\prime} \mathrm{N} 21^{\circ} 1^{\prime} \mathrm{E}$ ). The remains have been found in a layer deposited over the Vistula River, and by stratigraphical relative dating it was assumed, that the skull was about $7000 \mathrm{yr}$ old. However, the remains were not accompanied by any archaeological material (Szlachetko et al. 1964) and no chemical analysis has been conducted so far. The skull may have been subjected to conservation.

\section{Wieliszew}

In 1961, the human remains from Wieliszew XI were excavated from a large single dune situated on the left bank of the River Narew (52 $\left.27^{\prime} 00^{\prime \prime} \mathrm{N} 20^{\circ} 58^{\prime} 08^{\prime \prime} \mathrm{E}\right)$. The site is approximately $1 \mathrm{~km}$ from the river (Więckowska 1985). The human material consists of numerous small bone fragments (Figure 1) with a light yellowish color and some gray infusions. A strong degree of mineralization together with cracks of the lamina suggest that this material was cremated. However, the lack of significant deformation of these particular bone fragments shows that the material was not subjected to high temperatures (Wiercińska and Szlachetko 1977). Thus, cremation at low temperature is proposed. In 1962, three fragments of these bones were investigated by using the fluorine-apatite (F/Apatite) method, giving an estimated date of about 4900-4100 BC, but further revision by Wysoczański-Minkowicz (1979) with the use of the fluoro-chloro-apatite method ( $\mathrm{F} / \mathrm{Cl} /$ Apatite) provided an older age of ca. $5850 \mathrm{BC}$.

\section{Woźna Wieś}

The fragments of a human cranium belonging to an adult with an undetermined age and gender were discovered in 1961 in Woźna Wieś, a village near the Dręstwo Lake, from which the River Jegrznia outflows, belonging to the Elk Lakeland (53 40 $53^{\prime \prime} \mathrm{N} 22^{\circ} 45^{\prime} 06^{\prime \prime} \mathrm{E}$; Sulgustowska 1990b; Tobolski and Żurek 2012). Paleolithic, Mesolithic, and Neolithic settlements have been discovered on a sandur (outwash plain) and excavated over the years 1974-1978. The traces of the settlement occurred in the lakeside arable fields approximately $500 \mathrm{~m}$ from the exiting River Jegrznia. In addition to the abundant flint artifacts, moose and reindeer remains were found in a layer dated to the Alleröd interstadial, as well as subsequent forest animal remains (bison, deer, sheep, and horse) and human bones. The fragments have been glued together to reconstruct the skull shape (see Figure 1).

\section{METHODS}

The research methods applied within this study comprise firstly of collagen extraction from bones according to a modified Longin's protocol in the Gliwice Radiocarbon Laboratory (Piotrowska and Goslar 2002; Piotrowska 2013). All bone samples were cleaned in an ultrasonic bath in demineralized water, then dried and ground in a ball mill. The powdered bone was treated with use of $0.5 \mathrm{M}$ hydrochloric acid in a glass vial at a room temperature to decompose the mineral fraction. The acid was replaced several times, and the reaction was considered complete when $\mathrm{pH}$ stabilized at $<1$ and no bubbles were observed. The whole procedure took 1-2 working days. The insoluble residue was rinsed with demineralized water to neutral $\mathrm{pH}$. Next, gelatinization was performed for all the samples: the residue was acidified and kept in $80^{\circ} \mathrm{C}$ for $12 \mathrm{hr}$ in an acidic solution $(\mathrm{HCl}, \mathrm{pH}=3)$. The obtained supernatant was centrifuged, filtered, put in a glass vial and dried in an oven at $75^{\circ} \mathrm{C}$. Ultrafiltration was not used. Hereafter, we refer to recovered material as the gelatin, and to this treatment as Treatment A. 
In Treatment A, the demineralized residue was not subjected to any $\mathrm{NaOH}$ treatment, due to the risk of collagen loss. The second batch of samples was treated with $0.1 \mathrm{M} \mathrm{NaOH}$ for $30 \mathrm{~min}$ at a room temperature, after the demineralization step, and rinsed with demineralized water to a neutral $\mathrm{pH}$. Next, the gelatinization was performed as described above. Hereafter, we refer to this procedure as Treatment $\mathrm{B}$.

The subsample of gelatin was subjected to graphite preparation using an AGE-3 system equipped with a VarioMicroCube by Elementar elemental analyzer and automated graphitization unit (Nemec et al. 2010; Wacker et al. 2010). This analyzer (hereafter called VMC-EA) was calibrated with use of acetanilide and sulphanilamide reference materials to obtain the $\% \mathrm{C}$, $\% \mathrm{~N}$ and $\mathrm{C} / \mathrm{N}$ atomic ratios. The ${ }^{14} \mathrm{C}$ concentrations in graphite produced from unknown samples, Oxalic Acid II standards, and coal blanks have been measured by the DirectAMS laboratory, Bothell, USA (Zoppi et al. 2007; Zoppi 2010). The results are reported in Table 1 (reference samples) and Table 2 (archaeological samples). The ${ }^{14} \mathrm{C}$ dates have been subjected to calibration with the use of OxCal v4.3.2 (Bronk Ramsey 2009) and IntCal13 calibration curve (Reimer et al. 2013).

Another gelatin subsample was assigned for stable isotope analysis of the carbon and nitrogen $\left(\delta^{13} \mathrm{C}, \delta^{15} \mathrm{~N}\right), \% \mathrm{C}, \% \mathrm{~N}$, and $\mathrm{C} / \mathrm{N}_{\text {at }}$ quantities by using a CF-EA-IRMS system working in the Gliwice Mass Spectrometry Laboratory. The equipment comprises of a EuroVector elemental analyzer and continuous-flow IsoPrime mass spectrometer. The instrument precision is $0.1 \% 0$ for $\delta^{13} \mathrm{C}$ and $0.3 \%$ for $\delta^{15} \mathrm{~N}$. The elemental analyzer (hereafter called EV-EA) was calibrated for $\mathrm{C} / \mathrm{N}_{\mathrm{at}}$ ratios with use of UREA and EMA P2 standards. At least three subsamples from each collagen sample have been prepared, along with the standards: IAEA-C8, IAEA-C5 and EMA P2 for carbon, as well as $\mathrm{NO}_{3}$ and USGS34 for nitrogen. The reported values of $\delta^{13} \mathrm{C}$ and $\delta^{15} \mathrm{~N}$ have been normalized to the VPDB and AIR scales, respectively. The average values are calculated and presented in Table 2 and in Figure 4.

The two elemental analyzers require considerably different sample masses. One gelatin subsample of 3-5 mg was combusted for graphitization in VMC-EA, while for EV-EA the required sample masses of approximately $0.25-0.30 \mathrm{mg}$.

Two of the reference bone samples (VIRI H and E, GdA-5341 and 5342) were prepared in the second batch of samples. The SIRI C (GdA-5339) bone was prepared in 2014 with the inclusion

Table 1 Results for international ${ }^{14} \mathrm{C}$ intercomparison bone samples, prepared with Treatment $\mathrm{B}$ method (gelatinization and $\mathrm{NaOH}$ wash). Consensus values after Scott et al. (2010) for VIRI and Scott et al. (2017) for SIRI. LoB: limit of blank, i.e. the highest apparent ${ }^{14} \mathrm{C}$ concentration reported as $F_{m}$ value (no correction for background).

\begin{tabular}{llcccccc}
\hline Lab no. & \multicolumn{1}{c}{ Sample } & $\begin{array}{c}\text { Coll. } \\
\text { yield }(\%)\end{array}$ & $\% \mathrm{C}$ & $\% \mathrm{~N}$ & $\begin{array}{c}\mathrm{C} / \mathrm{N}_{\mathrm{at}} \\
\text { VMC-EA }\end{array}$ & $\begin{array}{c}\text { Consensus } \\
\text { value }\end{array}$ & Age ${ }^{14} \mathrm{C}$ BP \\
\hline 5341 & $\begin{array}{l}\text { VIRI H Whale } \\
\text { bone }\end{array}$ & 13 & 37.3 & 13.5 & 3.2 & $9528 \pm 7$ & $9535 \pm 45$ \\
5342 & $\begin{array}{l}\text { VIRI E } \\
\text { Mammoth bone }\end{array}$ & 11 & 41.3 & 14.9 & 3.2 & $39305 \pm 21$ & $35600 \pm 480$ \\
5339 & $\begin{array}{l}\text { SIRI C } \\
\text { Mammoth bone } \\
\text { (collagen) }\end{array}$ & - & 28.1 & 10.6 & 3.1 & $\begin{array}{c}0.00895 \\
(\mathrm{LoB})\end{array}$ & $\begin{array}{c}F_{m}=0.00679 \\
\pm 0.00020\end{array}$ \\
& & & & & & \\
\hline
\end{tabular}


Table 2 Results of $\mathrm{C} / \mathrm{N}_{\mathrm{at}}$, stable isotope, ${ }^{14} \mathrm{C}$ determinations, and calibration. Treatment method A: gelatinization, treatment method B: gelatinization with alkali wash. Elemental analyzers: EV_-EuroVector (connected to IRMS system), VMC_VarioMicroCube (connected to graphitization system). The calibration was performed with the use of OxCal v4.3.2 (Bronk Ramsey 2009) and IntCal13 calibration curve (Reimer et al. 2013). * = radiocarbon date reported by Sulgostowska (1990a), recalibrated.

\begin{tabular}{|c|c|c|c|c|c|c|c|c|c|c|c|}
\hline Sample name & $\begin{array}{l}\text { Treat. } \\
\text { meth. }\end{array}$ & $\begin{array}{l}\text { Lab no. } \\
\text { GdA- }\end{array}$ & $\begin{array}{l}\text { Coll. } \\
\text { yield, } \\
\%\end{array}$ & $\begin{array}{l}\text { EA } \\
\text { used }\end{array}$ & $\% \mathrm{C}$ & $\% \mathrm{~N}$ & $\mathrm{C} / \mathrm{N}_{\mathrm{at}}$ & $\begin{array}{l}\delta^{13} \mathrm{C}, \%{ }_{0} \\
\mathrm{VPDB}\end{array}$ & $\begin{array}{c}\delta^{15} \mathrm{~N}, \% 0 \\
\text { AIR }\end{array}$ & $\underset{\text { BP }}{\text { Age }}{ }^{14} \mathrm{C}$ & $\begin{array}{c}\text { Calibrated age range } \\
(95.4 \%)\end{array}$ \\
\hline $\begin{array}{l}\text { Janisławice Tibia } \\
\text { Cortical bone } \\
\text { fragment }\end{array}$ & $\overline{\mathrm{A}}$ & 236 & 4.3 & $\mathrm{EV}$ & 12.1 & 4.0 & 3.5 & $-22.2 \pm 0.1$ & $10.4 \pm 0.1$ & $5875 \pm 40$ & $\begin{array}{l}95.4 \% \text { probability } \\
\text { 4840BC }(93.3 \%) 4670 \mathrm{BC} \\
4635 \mathrm{BC}(2.1 \%) 4620 \mathrm{BC}\end{array}$ \\
\hline \multirow[t]{2}{*}{$\begin{array}{l}\text { Janisławice Femur } \\
\text { Cortical bone } \\
\text { fragment }\end{array}$} & A & 4237 & - & EV & 23.8 & 7.1 & 3.9 & $-21.5 \pm 0.1$ & $11.2 \pm 0.1$ & $6570 \pm 40$ & $\begin{array}{l}95.4 \% \text { probability } \\
5615 \mathrm{BC}(11.8 \%) 5590 \mathrm{BC} \\
5570 \mathrm{BC}(83.6 \%) 5475 \mathrm{BC}\end{array}$ \\
\hline & B & 5133 & 5.9 & $\begin{array}{c}\text { EV } \\
\text { VMC }\end{array}$ & $\begin{array}{l}39.5 \\
44.3\end{array}$ & $\begin{array}{l}13.3 \\
15.0\end{array}$ & $\begin{array}{l}3.5 \\
3.4\end{array}$ & $-20.7 \pm 0.2$ & $10.7 \pm 0.1$ & $6885 \pm 30$ & $\begin{array}{l}95.4 \% \text { probability } \\
5840 \mathrm{BC}(95.4 \%) 5715 \mathrm{BC}\end{array}$ \\
\hline $\begin{array}{l}\text { Janisławice } 2 \\
\text { Cortical bone } \\
\text { fragment }\end{array}$ & B & 5288 & 5.0 & $\begin{array}{l}\text { EV } \\
\text { VMC }\end{array}$ & $\begin{array}{l}41.6 \\
44.6\end{array}$ & $\begin{array}{l}15.1 \\
15.9\end{array}$ & $\begin{array}{l}3.2 \\
3.3\end{array}$ & $-20.7 \pm 0.2$ & $9.8 \pm 0.1$ & $4940 \pm 60$ & $\begin{array}{l}95.4 \% \text { probability } \\
3940 \mathrm{BC}(10.6 \%) 3860 \mathrm{BC} \\
3815 \mathrm{BC}(84.8 \%) 3635 \mathrm{BC}\end{array}$ \\
\hline $\begin{array}{l}\text { Janisławice Jan. }{ }^{*} \\
\text { Femur bone } \\
\text { (complete) }\end{array}$ & A & Gd-2432 & 一 & 一 & - & - & - & - & - & $6580 \pm 80$ & $\begin{array}{l}95.4 \% \text { probability } \\
5645 \mathrm{BC}(95.4 \%) 5375 \mathrm{BC}\end{array}$ \\
\hline \multirow[t]{2}{*}{$\begin{array}{l}\text { Giżycko } 1 \\
\text { Rib fragment, } \\
\text { 3-yr-old child }\end{array}$} & A & 4562 & 11.4 & EV & 4.27 & 0.98 & 5.1 & $-20.3 \pm 0.1$ & $13.8 \pm 0.3$ & $7050 \pm 35$ & $\begin{array}{l}95.4 \% \text { probability } \\
6010 \mathrm{BC}(93.7 \%) 5875 \mathrm{BC} \\
5860 \mathrm{BC}(1.7 \%) 5850 \mathrm{BC}\end{array}$ \\
\hline & B & 5134 & 8.5 & $\begin{array}{l}\text { EV } \\
\text { VMC }\end{array}$ & $\begin{array}{l}37.7 \\
40.8\end{array}$ & $\begin{array}{l}13.3 \\
13.5\end{array}$ & $\begin{array}{l}3.3 \\
3.5\end{array}$ & $-19.4 \pm 0.1$ & $13.8 \pm 0.2$ & $7770 \pm 35$ & $\begin{array}{l}95.4 \% \text { probability } \\
6655 \mathrm{BC}(95.4 \%) 6500 \mathrm{BC}\end{array}$ \\
\hline \multirow[t]{2}{*}{$\begin{array}{l}\text { Giżycko } 4 \\
\text { Phalanx, } \\
\text { female adult }\end{array}$} & A & 4565 & 22.3 & EV & 1.90 & 0.33 & 6.7 & $-22.4 \pm 0.1$ & $10.0 \pm 0.1$ & $6200 \pm 25$ & $\begin{array}{l}95.4 \% \text { probability } \\
5280 \mathrm{BC}(0.5 \%) 5275 \mathrm{BC} \\
5225 \mathrm{BC}(94.9 \%) 5055 \mathrm{BC}\end{array}$ \\
\hline & B & 5131 & 2.7 & $\begin{array}{l}\text { EV } \\
\text { VMC }\end{array}$ & $\begin{array}{l}36.9 \\
38.7\end{array}$ & $\begin{array}{l}13.2 \\
13.1\end{array}$ & $\begin{array}{l}3.3 \\
3.4\end{array}$ & $-20.6 \pm 0.1$ & $11.9 \pm 0.2$ & $7600 \pm 45$ & $\begin{array}{l}95.4 \% \text { probability } \\
6565 \mathrm{BC}(2.8 \%) 6545 \mathrm{BC} \\
6530 \mathrm{BC}(92.6 \%) 6390 \mathrm{BC}\end{array}$ \\
\hline
\end{tabular}


Table 2 (Continued)

\begin{tabular}{|c|c|c|c|c|c|c|c|c|c|c|c|}
\hline Sample name & $\begin{array}{l}\text { Treat. } \\
\text { meth. }\end{array}$ & $\begin{array}{l}\text { Lab no. } \\
\text { GdA- }\end{array}$ & $\begin{array}{l}\text { Coll. } \\
\text { yield, } \\
\%\end{array}$ & $\begin{array}{c}\text { EA } \\
\text { used }\end{array}$ & $\% \mathrm{C}$ & $\% \mathrm{~N}$ & $\mathrm{C} / \mathrm{N}_{\mathrm{at}}$ & $\begin{array}{c}\delta^{13} \mathrm{C}, \% \\
\mathrm{VPDB}\end{array}$ & $\begin{array}{c}\delta^{15} \mathrm{~N}, \% 0 \\
\mathrm{AIR}\end{array}$ & $\underset{\mathrm{BP}}{\mathrm{Age}}{ }^{14} \mathrm{C}$ & $\begin{array}{c}\text { Calibrated age range } \\
(95.4 \%)\end{array}$ \\
\hline $\begin{array}{l}\text { Giżycko } 2 \\
\text { Phalanx, 1.5-yr- } \\
\text { old child }\end{array}$ & A & 4563 & 8.9 & EV & 4.28 & 0.96 & 5.2 & $-20.9 \pm 0.2$ & $13.8 \pm 0.4$ & $7275 \pm 35$ & $\begin{array}{l}95.4 \% \text { probability } \\
6220 \mathrm{BC}(95.4 \%) 6065 \mathrm{BC}\end{array}$ \\
\hline \multirow[t]{2}{*}{$\begin{array}{l}\text { Giżycko } 3 \\
\text { Rib, adult }\end{array}$} & A & 4564 & 8.6 & EV & 7.1 & 1.9 & 4.4 & $-19.8 \pm 0.1$ & $13.8 \pm 0.2$ & $7230 \pm 30$ & $\begin{array}{l}95.4 \% \text { probability } \\
6210 \mathrm{BC}(28.3 \%) 6135 \mathrm{BC} \\
6125 \mathrm{BC}(67.1 \%) 6025 \mathrm{BC}\end{array}$ \\
\hline & B & 5130 & 11.3 & $\begin{array}{l}\text { EV } \\
\text { VMC }\end{array}$ & $\begin{array}{l}39.0 \\
43.6\end{array}$ & $\begin{array}{l}13.7 \\
15.3\end{array}$ & $\begin{array}{l}3.3 \\
3.3\end{array}$ & $-19.6 \pm 0.1$ & $14.5 \pm 0.1$ & $7860 \pm 30$ & $\begin{array}{l}95.4 \% \text { probability } \\
6815 \mathrm{BC}(95.4 \%) 6635 \mathrm{BC}\end{array}$ \\
\hline $\begin{array}{l}\text { Warsaw Grochów } \\
\text { Cranium, 9-yr- }\end{array}$ & A & 4566 & 26.9 & $\mathrm{EV}$ & 22.7 & 6.3 & 4.2 & $-15.9 \pm 0.2$ & $8.7 \pm 0.1$ & $2820 \pm 25$ & $\begin{array}{l}95.4 \% \text { probability } \\
1040 \mathrm{BC}(95.4 \%) 910 \mathrm{BC}\end{array}$ \\
\hline old female child & B & 5132 & 12.5 & $\begin{array}{c}\text { EV } \\
\text { VMC }\end{array}$ & $\begin{array}{l}39.2 \\
46.1\end{array}$ & $\begin{array}{l}13.1 \\
15.4\end{array}$ & $\begin{array}{l}3.5 \\
3.5\end{array}$ & $-16.6 \pm 0.1$ & $10.5 \pm 0.2$ & $3075 \pm 30$ & $\begin{array}{l}95.4 \% \text { probability } \\
1415 \mathrm{BC}(95.4 \%) 1260 \mathrm{BC}\end{array}$ \\
\hline $\begin{array}{l}\text { Wieliszew } \\
\text { Small bone } \\
\text { fragments }\end{array}$ & $\begin{array}{l}\mathrm{A} \\
\mathrm{B}\end{array}$ & $\begin{array}{l}4568 \\
5129\end{array}$ & $\begin{array}{c}14.9 \\
1.6\end{array}$ & $\begin{array}{l}\mathrm{EV} \\
\mathrm{EV}\end{array}$ & $\begin{array}{c}0.093 \\
0.43\end{array}$ & $\begin{array}{c}0.022 \\
0.15\end{array}$ & $\begin{array}{l}4.9 \\
3.3\end{array}$ & $\begin{array}{l}-23.8 \pm 0.1 \\
-\end{array}$ & $\begin{array}{c}5.7 \pm 0.4 \\
-\end{array}$ & - & - \\
\hline \multirow[t]{2}{*}{$\begin{array}{l}\text { Woźna Wieś } \\
\text { Cranium, adult }\end{array}$} & A & 4567 & 20.0 & $\mathrm{EV}$ & 0.23 & 0.026 & 10.3 & $-25.0 \pm 0.3$ & $5.4 \pm 0.1$ & $510 \pm 40$ & $\begin{array}{l}95.4 \% \text { probability } \\
\text { 1320AD }(14.7 \%) \text { 1355AD } \\
\text { 1390AD }(80.7 \%) 1450 \mathrm{AD}\end{array}$ \\
\hline & B & 5135 & 4.5 & $\begin{array}{c}\mathrm{EV} \\
\mathrm{VMC}\end{array}$ & $\begin{array}{l}36.5 \\
38.1\end{array}$ & $\begin{array}{l}12.8 \\
12.5\end{array}$ & $\begin{array}{l}3.3 \\
3.5\end{array}$ & $-19.4 \pm 0.1$ & $13.7 \pm 0.2$ & $195 \pm 40$ & $\begin{array}{l}95.4 \% \text { probability } \\
\text { 1640AD }(23.3 \%) 1700 \mathrm{AD} \\
\text { 1720AD }(47.9 \%) \text { 1820AD } \\
\text { 1830AD }(5.6 \%) 1880 \mathrm{AD} \\
\text { 1915AD }(18.6 \%) \ldots\end{array}$ \\
\hline
\end{tabular}


of alkali treatment (Piotrowska and Goslar 2002) and the stored gelatin was re-dissolved, filtered with a nylon woven net filter, and dried before combustion and graphitization.

\section{RESULTS AND DISCUSSION}

The measurement results for reference bone samples are listed in Table 1, and the results of the archaeological samples for both treatments are listed in Table 2. Unfortunately, the material for two of the samples (Giżycko 2 and Janisławice Tibia S.) was not available for repeated analysis with alkali treatment. The calibration plots are presented in Figure 3, while Figure 4 shows the stable isotope data.

\section{Quality Indicators and ${ }^{14} \mathrm{C}$ Results}

The first batch of gelatin, prepared without a $\mathrm{NaOH}$ wash by Treatment $\mathrm{A}$, yielded unsatisfactory results, in terms of the $\mathrm{C} / \mathrm{N}_{\mathrm{at}}$ ratios $(3.5-10.3)$ and depleted $\% \mathrm{C}$ and $\% \mathrm{~N}$ for almost all the samples (Table 2). The average gelatin yield was $14.6 \%$. Therefore, additional sample material was collected, and the preparation procedure was repeated with an alkali treatment step (Treatment B).

Most of the Treatment B samples yielded less gelatin (6.5\% on average) than the previous ones. Quality indicators fell within acceptable ranges, with $\mathrm{C} / \mathrm{N}_{\mathrm{at}}$ values ranging from 3.2 to 3.5 and the expected carbon and nitrogen content (Table 2). In addition, two independent analysis were performed with two elemental analyzers. The results for $\mathrm{C} / \mathrm{N}_{\mathrm{at}}$ values do not differ by more than 0.2 . This difference is concordant with the reported values for laboratory intercomparison studies (Sealy et al. 2014), and the uncertainty of $\mathrm{C} / \mathrm{N}$ results reported by ScireClabrisotto et al. (2013) and Svyatko et al. (2015).

The results for reference bone material indicate a good quality of gelatin with $\mathrm{C} / \mathrm{N}_{\mathrm{at}} 3.1-3.2$ (Table 1). The VIRI $\mathrm{H}$ determined age agrees perfectly with the consensus value within 1-sigma interval. The SIRI C sample, which may be regarded as background material, gave a $F_{m}$ value $0.00679 \pm 0.00020$, which is even lower than the reported consensus value. The most confusing result was obtained for VIRI E, which gave an age ca. $3700{ }^{14} \mathrm{C} \mathrm{yr}$ younger than consensus value. While it is a considerable shift, a very wide range of results for this particular bone sample was reported by Scott et al. (2010): the interquartile values were 35,320 and $40,400{ }^{14} \mathrm{C}$ BP $(n=57)$. After the outliers were omitted the interquartile results, from AMS, were 36,540 and $40,648{ }^{14} \mathrm{C} \mathrm{BP}(\mathrm{n}=40)$. The resulting consensus value was calculated to $39,305 \pm 121{ }^{14} \mathrm{C} B P$, based on $\mathrm{n}=28$ dates. According to the methodology applied by Scott et al. (2010), our result would not be considered as an outlier removed in the first step. The difference from the median (equal to $39,695{ }^{14} \mathrm{C} \mathrm{BP}$ ) is 4095, which is less than 7620 (1.5 times the interquartile range, IQR $=5080$ ). However, our result is on the edge of acceptability and indicates an action should be undertaken to further evaluate the reasoning behind this data. It is most likely that our method was not sufficient enough to extract the material with a proper purity. The use of longer alkali treatment, ultrafiltration or a selection of more specific chemical components should be considered. Despite the disputable result for the VIRI E sample, which proved to be problematic for many laboratories, the demonstrated reasonable ${ }^{14} \mathrm{C}$ background level allows to expect our results to be accurate.

Five of the ${ }^{14} \mathrm{C}$ ages obtained for the archaeological samples from Treatment $\mathrm{B}$ are older than the ${ }^{14} \mathrm{C}$ ages for Treatment A by $250-1400{ }^{14} \mathrm{C}$ yr. This indicates the presence of a 


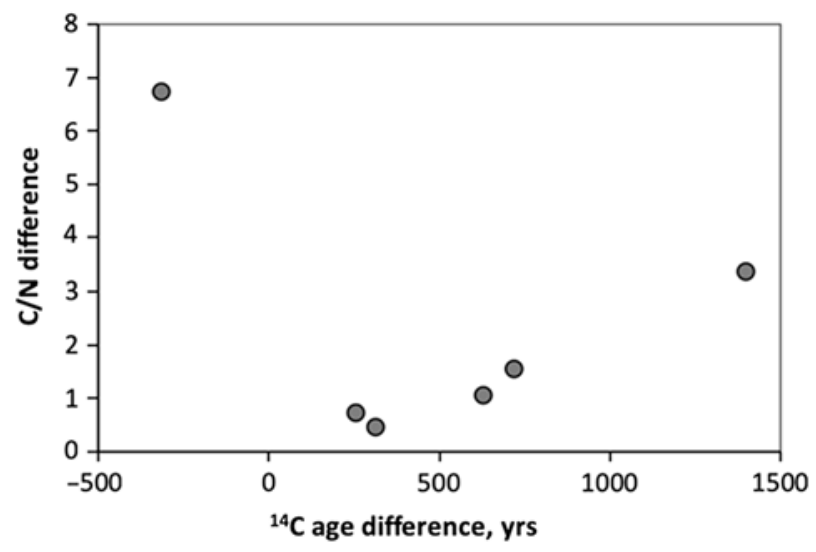

Figure 2 Differences in the $\mathrm{C} / \mathrm{N}_{\text {at }}$ ratios and the ${ }^{14} \mathrm{C}$ ages between the results obtained for Treatment A (simple gelatinization) and Treatment B (gelatinization with alkali wash).

contaminant which is younger than the age of bones. Adding this to elevated $\mathrm{C} / \mathrm{N}_{\mathrm{at}}$ ratios for the Treatment A gelatin, the most probable contaminant is a substance rich in carbon, which was removed by the alkali treatment in Treatment B. The difference between ages for the same samples subjected to Treatments $A$ and $B$ is proportional to the difference in $C / N_{a t}$ ratios for the same samples (Figure 2). Also, the $\delta^{13} \mathrm{C}$ was shifted towards values more common for human bone collagen: increased for four of them (Giżycko and Janisławice sites) and decreased for Warsaw-Grochów sample (Figure 3).

In the case of the Woźna Wieś sample, the new date is $320 \mathrm{yr}$ younger. This sample is also characterized by a significant $\mathrm{C} / \mathrm{N}_{\mathrm{at}}$ shift from 10.3 to 3.5 between the Treatments $\mathrm{A}$ and $\mathrm{B}$, and a huge difference in $\% \mathrm{C}$ and $\% \mathrm{~N}$. In this case the contaminant had a carbon content much higher than collagen, and was older than the bone sample. The significant improvement in a quality of dated material is seen also in $\delta^{13} \mathrm{C}$ (shift from $-25 \%$ to $-19.4 \%$ ) and $\delta^{15} \mathrm{~N}$ (from $5.4 \%$ to $13.7 \%$ ).

\section{Janisławice}

For the Janisławice hunter, two cortical bone fragments have been subjected to ${ }^{14} \mathrm{C}$ AMS dating with Treatment A. The one from the tibia bone yielded an age of $5875 \pm 40 \mathrm{BP}$ $\left(\mathrm{C} / \mathrm{N}_{\mathrm{at}}=3.5\right)$, while the femur bone gave a distinctly older result by ca. $700 \mathrm{yr}(6570 \pm 40 \mathrm{BP}$, $\mathrm{C} / \mathrm{N}_{\mathrm{at}}=3.9$ ). This discrepancy is too large to be explained by turnover time in different bone fragments from a single individual, which is dozens of years higher. In the Treatment B the material was only available for the femur bone, and yielded a lower $\mathrm{C} / \mathrm{N}_{\text {at }}$ ratio (3.4-3.5), an acceptable $\% \mathrm{C}$ and $\% \mathrm{~N}$, and gave an even older age of $6885 \pm 30 \mathrm{BP}$.

For the Treatment $\mathrm{A}$ the values of $\delta^{13} \mathrm{C}$ and $\delta^{15} \mathrm{~N}$ are higher for the femur bone $(-21.5 \%$, $11.2 \%$ ) than for the tibia $(-22.2 \%, 10.4 \% 0)$. The $\delta^{13} \mathrm{C}$ is even higher for the femur sample treated with alkali $(-20.7 \% 0)$. The $\delta^{13} \mathrm{C}$ shows a rising tendency along with the decreasing $\mathrm{C} / \mathrm{N}_{\mathrm{at}}$. The humic substances, which are suspected to alter the Treatment A results, would most probably have a $\delta^{13} \mathrm{C}$ lower than $-25 \%$ and high $\mathrm{C} / \mathrm{N}_{\text {at }}$ ratio. Therefore, the observed $\delta^{13} \mathrm{C}$ and $\mathrm{C} / \mathrm{N}_{\text {at }}$ trends confirm this hypothesis. 

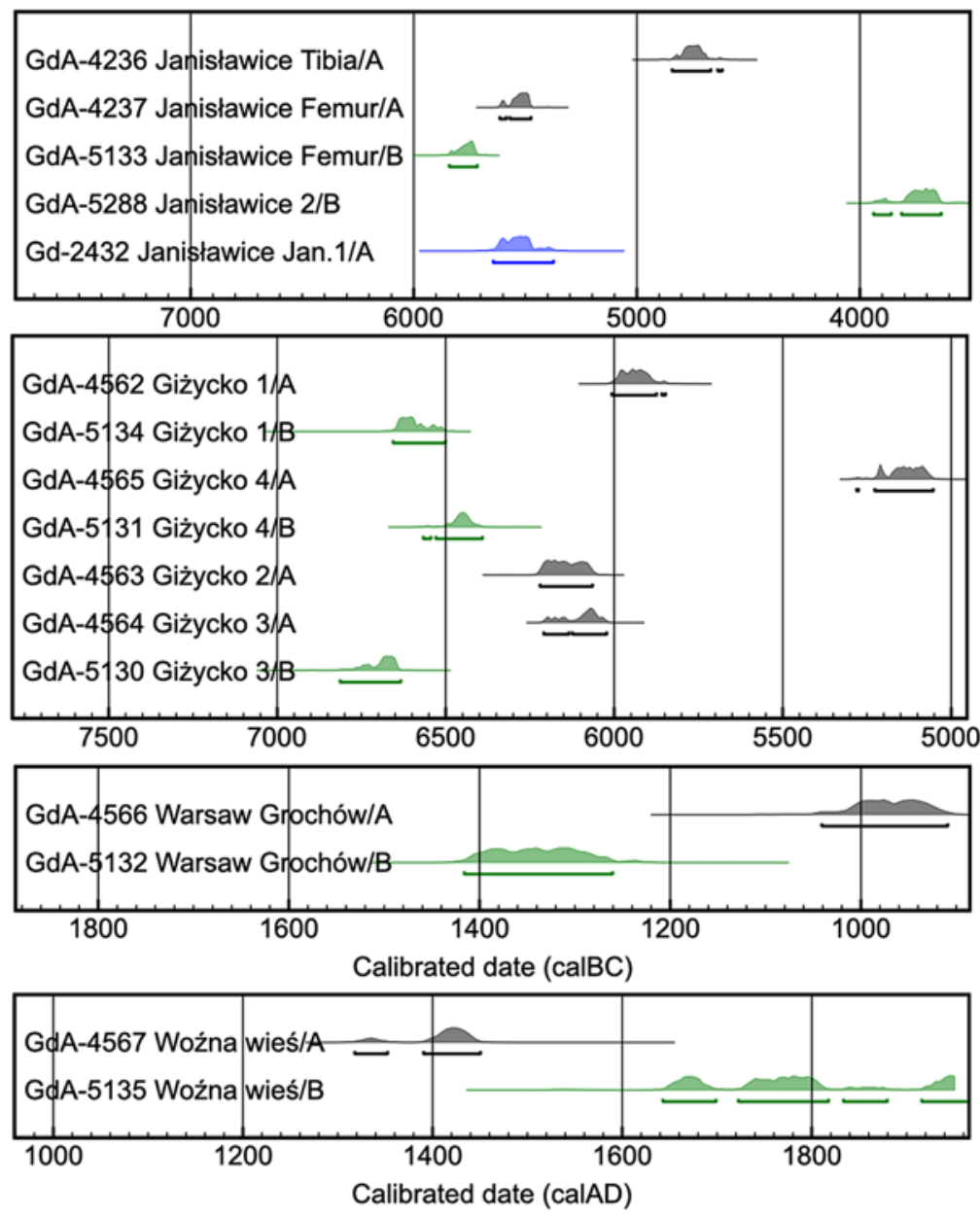

Figure 3 The calibration results of the ${ }^{14} \mathrm{C}$ dates; gray: Treatment A (simple gelatinization), green: Treatment $\mathrm{B}$ (gelatinization with alkali wash), blue: radiometric date. The ${ }^{14} \mathrm{C}$ dates have been subjected to calibration with the use of OxCal v4.3.2 (Bronk Ramsey 2009) and IntCal13 calibration curve (Reimer et al. 2013). (Please see electronic version for color figures.)

An AMS age of $6570 \pm 40 \mathrm{BP}(\mathrm{GdA}-4237)$ is in perfect accordance with the result of $6580 \pm 80$ (Gd-2432) obtained by radiometric ${ }^{14} \mathrm{C}$ dating on another femur bone (see Figure 3 ). Both samples were prepared with a similar methodology, namely without alkali treatment, and a similar influence of humic substances on the ${ }^{14} \mathrm{C}$ age can be deduced.

The youngest age $4940 \pm 60 \mathrm{BP}$ was obtained for the newly acquired bone fragment. The quality of the gelatin is acceptable with a $\mathrm{C} / \mathrm{N}_{\mathrm{at}}=3.3(44.6 \% \mathrm{C}$ and $15.9 \% \mathrm{~N})$, and stable isotope composition of $\delta^{13} \mathrm{C}=-20.7 \%$, in agreement with Janisławice femur bone. The $\delta^{15} \mathrm{~N}=9.8 \%$ is, however, lower by almost $1 \%$ in comparison with femur bone (see Figure 3 ). Thus, the discrepancy in the age with other Janisławice samples cannot be explained by contamination, but rather shows it is a fragment of another skeleton, younger by almost 2000 yr. Given the dubious provenience of this sample, this age should be regarded as unreliably associated with the Janisławice hunter skeleton. 


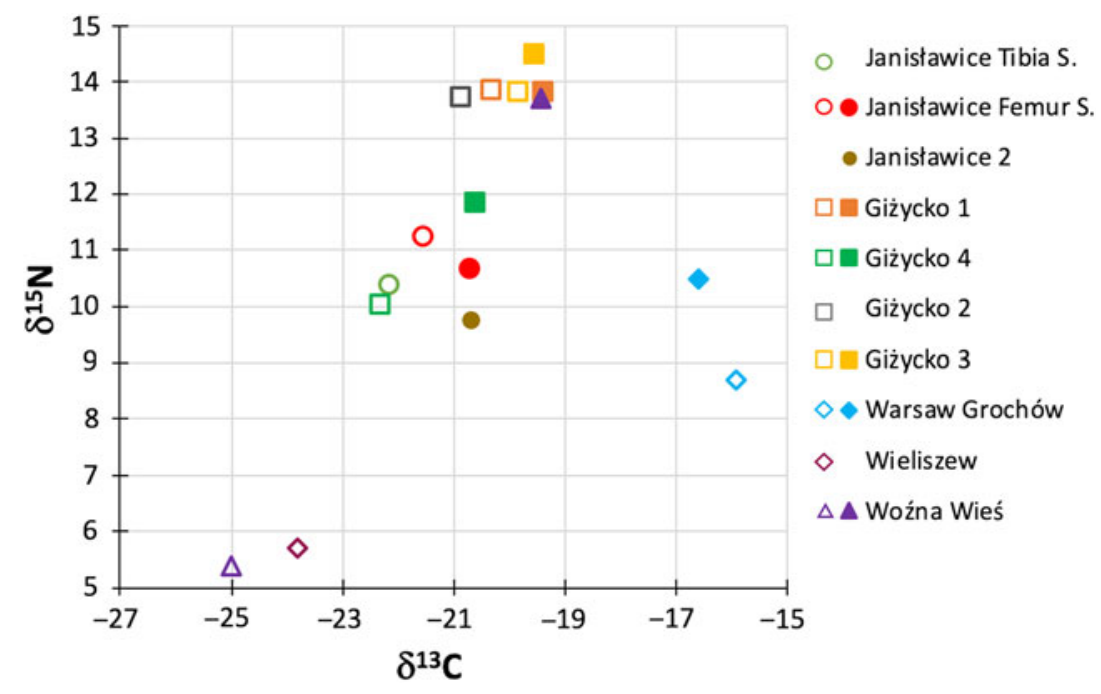

Figure 4 The stable isotope composition of investigated samples. Open symbols: Treatment A (simple gelatinization), filled symbols: Treatment B (gelatinization with alkali wash).

In the light of the obtained results the most reliable age of Janisławice hunter skeleton is connected with sample from femur bone, prepared with alkali wash, which is $6885 \pm 30 \mathrm{BP}$, and 5840-5715 cal BC (Table 2, Figure 3).

\section{Giżycko-Pierkunowo}

Four bone samples from this site have been subjected to analyses. All the $C / \mathrm{N}_{\mathrm{at}}$ values for the samples prepared with Treatment A were higher than for collagen (ranging from 4.4 to 6.8), but still the ages fell within the Mesolithic period. The gelatin samples from the Treatment B are characterized by a considerably lower $\mathrm{C} / \mathrm{N}_{\text {at }}$ ratios $(3.3-3.5)$ and their ${ }^{14} \mathrm{C}$ ages are shifted towards older values by 630,720 , and $1400 \mathrm{yr}$. The age difference is proportional to the $\mathrm{C} / \mathrm{N}_{\mathrm{at}}$ shift (Figure 2), implying the presence of the same contaminant, a younger material of elevated $\mathrm{C} / \mathrm{N}_{\mathrm{at}}$, which was removed during the alkali treatment.

The stable carbon and nitrogen isotope composition of the Giżycko samples is also altered by alkali treatment, most noticeably for the sample Giżycko 4 , along with the highest $C / \mathrm{N}_{\mathrm{at}}$ and ${ }^{14} \mathrm{C}$ age shift (Figure 4). In all cases the $\delta^{13} \mathrm{C}$ results for Treatment $\mathrm{B}$ are shifted towards more positive values. Therefore, the contamination by the humic substances of high carbon content and $\delta^{13} \mathrm{C}$ around $-25 \%$ is the most probable explanation for the rejuvenated ages obtained by Treatment A.

The additional material was not available for the Giżycko 2 sample, which in the first trial (Treatment A) gave gelatin with a $\mathrm{C} / \mathrm{N}_{\mathrm{at}}=4.9$ and age of $7275 \pm 35 \mathrm{BP}$. Following the trend presented in Figure 2, the correct age of this sample can be estimated to be at least $600-700$ yr older.

Freshwater food consumption by humans from Giżycko-Pierkunowo site is likely, as the location of the site is in a close vicinity to Lake Kisajno. Therefore, the freshwater reservoir effect (FRE), causing the ages to appear older than the actual age, is likely. 
The FRE is a strictly local effect, dependent on the reservoir age of lake-derived food and the proportion of this food in an individual's diet. According to the data presented by Sensuła et al. (2006), for Polish lakes the reservoir age for the organic fraction of lake sediments were: $T_{R}=171$ $\pm 76{ }^{14} \mathrm{C}$ yr for Lake Wigry (NE Poland, $90 \mathrm{~km}$ E from lake Kisajno), $\mathrm{T}_{\mathrm{R}}=539 \pm 60{ }^{14} \mathrm{C}$ years for Lake Gościąż (central Poland, $230 \mathrm{~km} \mathrm{SW}$ ), and $\mathrm{T}_{\mathrm{R}}=500 \pm 200{ }^{14} \mathrm{C} \mathrm{yr}$ for Lake Samle Duże (NE Poland, $85 \mathrm{~km} \mathrm{E}$ ). Using any of these values as FRE estimate may lead to incorrect conclusions, as the organic fraction of lake sediment undoubtedly contain some amount of terrestrial plants. Thus, the presence of a $T_{R}$ reaching a few centuries for Lake Kisajno is to be expected and regarded as minimal FRE estimate.

The stable carbon and nitrogen isotope composition of human bones is also affected by freshwater food consumption. The $\delta^{13} \mathrm{C}$ of the possible aquatic dietary component and the aquatic plants in NE Poland, are characterized by having relatively low $\delta^{13} \mathrm{C}$ values, close to terrestrial $\mathrm{C}_{3}$ plants. For the Wigry Lake, the average $\delta^{13} \mathrm{C}$ for contemporary aquatic plants is ca. $-25 \%$, while for terrestrial $\mathrm{C}_{3}$ plants the $\delta^{13} \mathrm{C}$ is equal to ca. $-26 \%$. For the Gościąż Lake, the values are ca. 2\%o lower (Sensuła et al. 2006). Similarly, Reitsema (2012) has shown a $\delta^{13} \mathrm{C}$ for fish bones ranging from $-21.6 \%$ to $-28.2 \%$. Consequently, the freshwater fish consumption may not be distinguishable by the $\delta^{13} \mathrm{C}$ values.

For fish from Polish lakes the relatively wide range of $\delta^{15} \mathrm{~N}$ was reported by Reitsema (2012): 6.6\% to $12.1 \%$ for medieval samples from Central Poland. The $\delta^{15} \mathrm{~N}$ for two investigated bones, Giżycko 1 (3-yr-old child): 13.8\%o, and Giżycko 3 (adult): 14.5\%o, are even more positive. For the adult it indicates a greater proportion of freshwater fish in the diet. Conversely, a $\delta^{15} \mathrm{~N}=11.9 \%$ for another female adult (Giżycko 4) does not suggest a freshwater diet component.

The $\delta^{15} \mathrm{~N}$ and $\delta^{13} \mathrm{C}$ of the 3 -yr-old child's bones (Giżycko 1 ) are shifted by ca. +2.6 and $+1.2 \%$, respectively, when compared with the values obtained for a female from the same grave (Giżycko 4). These differences are within the range expected for breast-feeding effect, or, less probable, are an effect of the elevated proportion of freshwater protein in a child's diet. The ${ }^{14} \mathrm{C}$ ages of the two samples are disparate within 2-sigma: $7770 \pm 35{ }^{14} \mathrm{C} \mathrm{BP}$ (child) and $7600 \pm 45{ }^{14} \mathrm{C} \mathrm{BP}$ (female), but the calibrated age ranges overlap in the period $6570-6500$ cal BC. Therefore, a coeval burial of a mother and her child cannot be excluded.

In order to estimate the FRE quantitatively, paired ${ }^{14} \mathrm{C}$ dating of terrestrial vs. freshwater species is typically carried out (e.g. Cook et al. 2001; Olsen et al. 2010; Piličiauskas and Heron 2015; Svyatko et al. 2015), which was unavailable for this site. An extensive research into stable isotope for a particular site is required and then the application of thorough modelling tools allows one to calculate the proportion of freshwater to terrestrial component in the diet (e.g. Sayle et al. 2016). A more detailed study on the isotope-based diet reconstructions may provide a prospect to re-evaluate the dates from the Giżycko site, until then the dates should be regarded as maximal.

\section{Warsaw-Grochów}

The skull of the 8/9-yr-old girl accidentally excavated in the riverine sediments, in Warsaw, was dated to an age a much younger age than expected stratigraphy. Although the carbon and nitrogen content were satisfactory $(22.7 \% \mathrm{C}$, and $6.3 \% \mathrm{~N})$, the $\mathrm{C} / \mathrm{N}_{\mathrm{at}}=4.2$ ratio of the first batch of gelatin was higher than the modern values, and the stable isotope results were as unexpected $\left(\delta^{13} \mathrm{C}=-15.9 \%\right.$ ond $\delta^{15} \mathrm{~N}=8.7 \%$ ). Therefore, the preservative(s) which may have been used are the suspected cause of the discrepancy in the results. Repeated 
preparation provided material which had good quality indicators $(12 \%$ collagen yield, $46 \% \mathrm{C}$, $\left.15 \% \mathrm{~N}, \mathrm{C} / \mathrm{N}_{\mathrm{at}}=3.5\right)$, and the age was shifted by almost 300 years to $3075 \pm 30{ }^{14} \mathrm{C} \mathrm{BP}(1415-$ 1260 cal BC). Still, the result does not confirm the Mesolithic age of this bone.

The stable isotope composition results are $\delta^{13} \mathrm{C}=-16.6 \%$ and $\delta^{15} \mathrm{~N}=10.5 \%$. The elevated $\delta^{13} \mathrm{C}$ indicates that the girl's diet was enriched in the ${ }^{13} \mathrm{C}$ isotope. At the present state of study, it might be cautiously concluded, that the girl consumed some $\mathrm{C}_{4}$ plant, e.g. millet, which has a carbon isotopic signature of ca. $\delta^{13} \mathrm{C}=-11 \%$ o (e.g. An et al. 2015) and which was been cultivated and consumed in Poland since ca. 2000 BC (Hunt et al. 2008; Reitsema 2012).

\section{Wieliszew}

The bones sample from the Wieliszew site yielded extremely small amount of gelatin residue, which was sufficient enough to only perform IRMS and $\mathrm{C} / \mathrm{N}_{\mathrm{at}}$ measurements, requiring micrograms of carbon, and attempts to obtain a graphite were unsuccessful. The $\mathrm{C} / \mathrm{N}_{\mathrm{at}}$ ratio of this material, from the Treatment $\mathrm{A}$, was 4.9 , clearly indicating the presence of a noncollagen component. Also, the $\delta^{13} \mathrm{C}=-23.8 \%$ and $\delta^{15} \mathrm{~N}=5.7 \%$ were unusual for a human bone, when compared to other results from this study. The second batch sample gave a collagen yield of $1.5 \%$ and a $\mathrm{C} / \mathrm{N}_{\mathrm{at}}=3.3$, which are acceptable values, but the carbon and nitrogen content was far too low $(0.43 \%$ and $0.15 \%)$. No other results were achievable due to the low amount of recovered material.

As described by Wysoczański-Minkowicz (1979), the bones have been burned but not subjected to high temperatures (Wiercińska and Szlachetko 1977), and in this process the collagen must have almost been completely lost. Wysoczański-Minkowicz (1979) attempted to date the bones with use of fluoro-chloro-apatite method ( $\mathrm{F} / \mathrm{Cl} / \mathrm{Apatite})$ and the result provided an age of ca. $5850 \mathrm{BC}$, which agrees with archaeological evidence and remains the only available independent age determination for this material.

\section{Woźna Wieś}

The first ${ }^{14} \mathrm{C}$ result obtained for Woźna Wieś sample using the Treatment A (GdA-4567, $510 \pm$ $40{ }^{14} \mathrm{C}$ BP) gave unexpectedly young results, which was inconsistent with archaeological evidence. The quality indicators prove the unreliability of the dating result, namely the carbon and nitrogen content were extremely low, 0.23 and $0.026 \%$, respectively. The $C / \mathrm{N}_{\text {at }}$ ratio was equal to 10.3 , while $\delta^{13} \mathrm{C}=-25 \%$ and $\delta^{15} \mathrm{~N}=5.4 \%$. The second date (Treatment $\mathrm{B}, \mathrm{GdA}-5135)$ was obtained on material with quality indicators characteristic of collagen $\left(\% \mathrm{C}=37, \% \mathrm{~N}=13, \mathrm{C} / \mathrm{N}_{\mathrm{at}}=3.5, \delta^{13} \mathrm{C}=-19.4 \%\right.$ ond $\delta^{15} \mathrm{~N}=13.7 \%$ ) , but gave an even younger age $195 \pm 40{ }^{14} \mathrm{C} \mathrm{BP}$. We conclude, that the dated material was contaminated by a component much older than the actual age of this sample. The glue, which had been used to reconstruct the skull, must have been present in the material despite physical cleaning before preparation, but the alkali treatment was sufficient enough to remove it. In any case, the dating results do not confirm a Mesolithic age for this material.

\section{CONCLUSIONS}

The Mesolithic age was confirmed for the Janisławice hunter, which can be placed at 5840-5715 cal BC. Similarly, the Giżycko-Pierkunowo site ages fall within the Mesolithic period. The youngest bone was determined to be $6570-6390$ cal $\mathrm{BC}$ for the female adult 
(Giżycko 4), and two other bones Giżycko 1 (child, ca. 3 yr old) and Giżycko 3 (adult, sex and age undetermined) gave slightly overlapping age ranges of 6660-6500 and 6815-6635 cal BC, respectively. However, their $\delta^{15} \mathrm{~N}$ indicated a proportion of freshwater fish in the diet, which can bias the ${ }^{14} \mathrm{C}$ dating results. The FRE for this site may reach a few centuries, thus their true ages may fall closer to Giżycko 1 in age.

The skull of the "little girl from Grochów" was dated to $1415-1260$ cal BC, thus it is not of Mesolithic age. Similarly, the bone from Woźna Wieś was dated to a much younger age, 1640 $1880 \mathrm{cal}$ AD. The sample from Wieliszew yielded no datable collagen material.

The investigated bone samples have been difficult material for ${ }^{14} \mathrm{C}$ dating. The presented research confirms, that ${ }^{14} \mathrm{C}$ dating of such relics should be accompanied by a critical assessment of the obtained dates. In this regard the suitability of $\mathrm{C} / \mathrm{N}_{\text {at }}$ ratios along with $\delta^{13} \mathrm{C}$ and $\delta^{15} \mathrm{~N}$ isotopic determinations was confirmed, similarly to previous studies. We also confirm that separation of purified component for dating should prevail over the will to destroy the minimum amount of the material.

\section{ACKNOWLEDGMENTS}

Funding provided in frame of National Science Centre (NCN) project "Old material with new methods: Using the latest bio-chemical analysis in studies of Mesolithic human remains from the Polish areas", no. 2014/15/HS3/02184, the Ministry of Higher Education and Research grants from the Silesian University of Technology, Institute of Physics, no. BKS-104/RIF/ 2016, BKS-101/RIF/2017, BK-243/RIF/2016, and BK-229/RIF/2017.

\section{REFERENCES}

Ambrose SH. 1990. Preparation and characterization of bone and tooth collagen for isotopic analysis. Journal of Archaeological Science 17:431-451.

An C-B, Dong W, Li H, Zhang P, Zhao Y, Zhao X, Yu S-Y. 2015. Variability of the stable carbon isotope ratio in modern and archaeological millets: Evidence from northern China. Journal of Archaeological Science 53:316-322.

Brock F, Higham T, Bronk Ramsey C. 2010. Pre-screening techniques for identification of samples suitable for radiocarbon dating of poorly preserved bones. Journal of Archaeological Science 37:855-865.

Bronk Ramsey C. 2009. Bayesian analysis of radiocarbon dates. Radiocarbon 51(1):337-360.

Buikstra JE, Ubelaker DH, editors. 1994. Standards for data collection from human skeletal remains. Fayetteville (AR): Arkansas Archeological Survey Research Series 44.

Chmielewska M. 1954. Grób kultury tardenuaskiej w Janisławicach, pow. Skierniewice. Archaeological News 20(1):23-48.

Cook GT, Bonsall C, Hedges REM, McSweeney K, Boronean V, Pettitt PB. 2001. A freshwater dietderived ${ }^{14} \mathrm{C}$ reservoir effect at the Stone Age sites in the Iron Gates Gorge. Radiocarbon 43(2A): 453-460.
Cyrek K. 1978. Nieznane zabytki z grobu w Janisławicach, woj. skierniewickie i nowe obserwacje nad tym zespołem [Unknown artefacts from the grave from Janislawice, province Skierniewice and new observations on this site]. Archaeological News 43(2):213-225.

DeNiro MJ. 1985. Postmortem preservation and alteration of in vivo bone collagen isotope ratios in relation to palaeodietary reconstruction. Nature 317:806-809.

Fuller BT, Fuller JL, Harris DA, Hedges REM. 2006. Detection of breastfeeding and weaning in modern human infants with carbon and nitrogen stable isotope ratios. American Journal of Physical Anthropology 129(2):279-293.

Gładykowska-Rzeczycka J. 1973. Próba przedstawienia problematyki paleografii na terenie Polski od czasów najdawniejszych do $\mathrm{V}$ w. n.e. [Attempt to present the problems of paleography on the Polish territory since ancient times until to the $5^{\text {th }}$ century]. Archeology of Poland 18(2): 279-327.

Głosik J. 1969a. Groby szkieletowe barwione ochra z Perkunowa, pow. Giżycko nad jez. Kisajno. Wiadomości Archeologiczne [Skeletal graves colored with ocher from Pierkunowo, Giżycko province over the lake Kisajno]. Wiadomości Archeologiczne 54(2):189-203. In Polish. 
Głosik J. 1969b. Wiek grobów szkieletowych barwionych ochrą, nad jeziorem Kisjano koło Giżycka [Chronological age of skeletal graves coloured ocher, from lake Kisajno near Giżycko]. Komunikaty Mazursko-Warmińskie 2:285-290. In Polish.

Gumiński W. 1995. Environment, economy and habitation during the Mesolithic at Dudka, Great Masurian Lakeland, NE Poland. Przeglad Archeologiczny 435-436.

Hunt HV, Vander Linden M, Liu X, MotuzaiteMatuzeviciute G, Colledge S, Jones MK. 2008. Millets across Eurasia: chronology and context of early records of the genera Panicum and Setaria from archaeological sites in the Old World. Vegetation History and Archaeobotany 17(1):5-18.

Kozłowski T. 1998. A Mesolithic human skeleton discovered at Kamieńskie, site 1, Orzesze commune, Suwałki province. Sprawozdania Archeologiczne 50:131-133. In Polish.

Lillie MC, Richards MP. 2000. Stable isotope analysis and dental evidence of diet at the MesolithicNeolithic transition in Ukraine. Journal of Archaeological Science 27(10):965-972.

Marchenko ZV, Orlova LA, Panov VS, Zubova AV, Molodin VI, Pozdnyakova OA, Grishin AE, Uslamin EA 2015. Paleodiet, radiocarbon chronology, and the possibility of freshwater reservoir effect for Preobrazhenka 6 burial ground, Western Siberia: preliminary results. Radiocarbon 57(4):595-610.

Meiklejohn C, Bosset G, Valentin F. 2010. Radiocarbon dating of Mesolithic human remains in France. Mesolithic Miscellany 21(1):10-56.

Nemec M, Wacker L, Gäggeler HW. 2010. Optimization of the graphitization process at AGE-1. Radiocarbon 52(3):1380-1393.

Olsen J, Heinemeier J, Lübke H, Lüth F, Terberger T. 2010. Dietary habits and freshwater reservoir effects in bones from a Neolithic NE German cemetery. Radiocarbon 52:635-644.

Pazdur A, Fogtman M, Michczyński A, Pawlyta J, Zając M. 2004. ${ }^{14} \mathrm{C}$ chronology of Mesolithic sties from Poland and the background of environmental changes. Radiocarbon 46(2):809-826.

Pazdur MF, Awsiuk R, Goslar T, Pazdur A, Walanus A, Zastawny A. 1994. Gliwice radiocarbon dates XI. Radiocarbon 36:257-279.

Piličiauskas G, Heron C. 2015. Aquatic radiocarbon reservoir offsets in the southeastern Baltic. Radiocarbon 57(4):539-556.

Piličiauskas G, Asheichyk V, Osipowicz G, Skipitytė R, Varul L, Kozakaitė J, Kryvaltsevich M, Vaitovich A, Lakiza V, Šapolaitè J, Ežerinskis Ž, Pamazanau M, Lucquin A, Craig OE, Robson HK. 2018. The Corded Ware culture in the Eastern Baltic: new evidence on chronology, diet, beaker, bone and flint tool function. Journal of Archaeological Science: Reports 21:538-552.
Piotrowska N, Goslar T. 2002. Preparation of bone samples in the Gliwice Radiocarbon Laboratory for AMS radiocarbon dating. Isotopes in Environmental and Health Studies 38(4): 267-275.

Piotrowska N. 2013. Status report of AMS sample preparation laboratory at GADAM Centre, Gliwice, Poland. Nuclear Instruments and Methods in Physics Research B 294:176-181.

Richards MP, Mays S, Fuller BT. 2002. Stable carbon and nitrogen isotope values of bone and teeth reflect weaning age at the Medieval Wharram Percy site, Yorkshire, UK. American Journal of Physical Anthropology 119: 205-210.

Reimer PJ, Bard E, Bayliss A, Beck JW, Blackwell PG, Bronk Ramsey C, Buck C, Cheng H, Edwards RL, Friedrich M, Grootes PM, Guilderson TP, Haflidason H, Hajdas I, Hatté? C, Heaton TJ, Hoffmann DL, Hogg AG, Hughen KA, Kaiser KF, Kromer B, Manning SW, Niu M, Reimer RW, Richards DA, Scott EM, Southon JR, Staff RA, Turney CSM, van der Plicht J. 2013. IntCal13 and Marine13 radiocarbon age calibration curves $0-50,000$ years cal BP. Radiocarbon 55(4):1869-1887.

Reitsema LJ. 2012. Stable carbon and nitrogen isotope analysis of human diet change in prehistoric and historic Poland [PhD thesis]. Graduate School of the Ohio State University.

Sayle KL, Hamilton WD, Gestsdóttir H, Cook GT. 2016. Modelling Lake Mývatn's freshwater reservoir effect: Utilization of the statistical program FRUITS to assist in the re-interpretation of radiocarbon dates from a cemetery at Hofstaðir, north-east Iceland. Quaternary Geochronology 36:1-11.

Schulting RJ, Richards MP. 2001. Dating women and becoming farmers: new palaeodietary and AMS dating evidence from the Breton Mesolithic cemeteries of Téviec and Hoëdic. Journal of Anthropological Archaeology 20(3):314-344.

Scirè Calabrisotto C, Fedi ME, Caforio L, Bombardieri L, Mando PA. 2013. Collagen quality indicators for radiocarbon dating of bones: new data on Bronze Age Cyprus. Radiocarbon 55(2-3):472-480.

Scott E, Cook G, Naysmith P. 2010. A report on Phase 2 of the Fifth International Radiocarbon Intercomparison (VIRI). Radiocarbon 52(3): 846-858.

Scott E, Naysmith P, Cook G. 2017. Should archaeologists care about ${ }^{14} \mathrm{C}$ intercomparisons? Why? A summary report on SIRI. Radiocarbon 59(5):1589-1596.

Sealy J, Johnson M, Richards M, Nehlich O. 2014. Comparison of two methods of extracting bone collagen for stable carbon and nitrogen isotope analysis: Comparing whole bone demineralization with gelatinization and ultrafiltration. Journal of Archaeological Science 47(1):64-69. 
Sensuła B, Böttger T, Pazdur A, Piotrowska N, Wagner R. 2006. Carbon and oxygen isotope composition of organic matter and carbonates in recent lacustrine sediments. Geochronometria 25:77-94.

Stanaszek MŁ, Mańkowska-Pliszka H. 2013. Nowe spojrzenie na "człowieka z Janisławic". Analiza antropologiczna-kliniczna szkieletu [New look at "Janisławice man". Anthropological-clinical analysis of the skeleton]. In: Brzeziński W, editor. Prehistoryczny łowca. Wystawa o człowieku z Janisławic [Prehistoric hunter. Exposition about man from Janisławice]. Warszawa: Wydawnictwo PMA. p 17-26. In Polish.

Stanaszek MŁ, Mańkowska-Pliszka H. 2015. A New osteological analysis of Janisławice man. Tagungen des Landesmuseums für Vorgeschichte Halle 13:1-8.

Stęślicka-Mydlarska W. 1954. Szczątki ludzkie znalezione w grobie tardenoaskim w Janisławicach, pow. Skierniewice [Human remains found in tardenoisian grave in Janisławice, Skierniewice district.]. Archaeological News 20(1):49-66. In Polish.

Sulgostowska Z. 1990a. The Janisławice burial from Poland: radiocarbon dating. Mesolithic Miscellany 11(2):2-5.

Sulgostowska Z. 1990b. Pochówek mezolityczny z okresu atlantyckiego w Woźnej Wsi, woj. Łomżyńskie [Mesolithic burial from Atlantic period in Wożna Wieś, Łomża voivodship]. Archaeology of Poland 35(1):47-56. In Polish.

Sulgostowska Z. 2006. Mesolithic mobility and contacts on areas of the Baltic Sea watershed, the Sudety, and Carpathian Mountains. Journal of Anthropological Archaeology 25:193-203.

Svyatko SV, Mertz IV, Reimer PJ. 2015. Freshwater reservoir effect on re-dating of Eurasian Steppe cultures: first results for Eneolithic and Early Bronze Age north-east Kazakhstan. Radiocarbon 57(4):625-644.

Szlachetko K, Trzeciakowski J, Wierciński A. 1964. Znalezisko czaszki ludzkiej z okresu atlantyckiego na terenie Grochowa II w Warszawie [Discovery of human skull from the Altantic period on the Grochów II area in Warsaw]. Archaeology of Poland 9(2):46-71. In Polish.

Szostek K, Głąb H, Lorkiewicz W, Grygiel R, Bogucki P. 2005. The diet and social paleostratigraphy of Neolithic agricultural population of the Lengyel culture from Osłonki (Poland). Anthropological Review 68:29-41.

Tisnérat-Laborde N, Valladas H, Kaltnecker E, Arnold M. 2003. AMS radiocarbon dating of bones at LSCE. Radiocarbon 45(3):409-419.
Tobolski K, Żurek S. 2012. O kulturowej roli obiektów i obszarów torfowiskowych - przegląd dotychczasowych dokonań. Cultural meaning of mires and wetlands - state of the research. Studia Limnologica et Telmatologica 6(1):2529. (In Polish).

Tomczyk J, Komarnitki J, Zalewska M, Lekszycki T, Olczak-Kowalczyk D. 2014. Fluorescence methods (VistaCam iX proof and DIAGNODent pen) for the detection of occlusal carious lesions in teeth recovered from archaeological context. American Journal of Physical Anthropology 154:525-534.

van Klinken GJ. 1999. Bone collagen quality indicators for palaeodietary and radiocarbon measurements. Journal of Archaeological Science 26:687-695.

Wacker L, Nemec M, Bourquin J. 2010. A revolutionary graphitisation system: fully automated, compact and simple. Nuclear Instruments and Methods in Physics Research B 268(7-8): 931-934.

Wiercińska A, Szlachetko K. 1977. Anthropological study of the human skull from Wieliszew, Warsaw Voivoship. Archeologia Polona 18: 187-204.

Więckowska H. 1985. Osadnictwo późnopaleolityczne i mezolityczne nad dolną Narwią [Late Palaeolithic and Mesolithic settlement by lower Narew River]. Ossolineum: Warsaw-Wroclaw. In Polish.

Witas H, Jędrychowska-Dańska K, Płoszaj T. 2013. Wstępne wyniki analizy DNA "człowieka z Janisławic" [Preliminary results of DNA analysis of "Janisławice man"]. In: Brzeziński W, editor. Prehistoryczny łowca. Wystawa o człowieku z Janisławic [Prehistoric hunter. Exposition about man from Janisławice]. Warszawa: Wydawnictwo PMA. p 27-28. In Polish.

Wysoczański-Minkowicz T. 1979. Wyniki oznaczeń wieku kości ludzkich ze stanowiska XI w Wieliszewie k/Nowego Dworu w woj. Warszawskim uzyskane metodą FCL/P i Coll (raport z badań, nie publikowany) [The results of age determination for human bones from Wieliszew XI site near Nowy Dwór, Warsaw voivodship with use of FCL/P and Coll method]. Unpublished report. In Polish.

Zoppi U, Crye J, Song Q, Arjomand A. 2007. Performance evaluation of the new AMS system at Accium BioSciences. Radiocarbon 49(1): 173-82.

Zoppi U. 2010. Radiocarbon AMS data analysis: from measured isotopic ratios to ${ }^{14} \mathrm{C}$ concentrations. Radiocarbon 52(1):165-170. 